\title{
IMPREDIKTABILITAS KEBIJAKAN LUAR NEGERI AMERIKA SERIKAT: \\ TANTANGAN DAN ANCAMAN REZIM DONALD TRUMP TERHADAP ASEAN
}

\author{
Dwi Ardiyanti \\ Program Studi Ilmu Hubungan Internasional \\ Universitas Potensi Utama \\ ardiyanti.1987@gmail.com
}

\begin{abstract}
Abstrak
Amerika Serikat merupakan negara yang berpengaruh besar dalam kerjasama dengan ASEAN (Association of Southeast Asia Nations). Kebijakan Luar Negeri Amerika berpengaruh terhadap rezim internasional. Arah kebijakan Luar Negeri Amerika Serikat yang ditentukan oleh presiden terpilih juga berpengaruh terhadap kawasan ASEAN yang sebagian besar negara anggotanya potensial sebagai pasar internasional. Negara Indonesia, Malaysia, Singapura, maupun Filipina merupakan contoh negara anggota ASEAN yang ikut terpengaruh oleh kebijakan Luar Negeri Amerika Serikat. Pada rezim Donald Trump, kebijakan Luar Negeri Amerika Serikat sangat sulit diramalkan. Hal ini merupakan tantangan tersendiri bagi negara anggota ASEAN yang masih mengandalkan investasi asing dan kerjasama dengan negara maju seperti Amerika Serikat. Aliansi negara Amerika Serikat di bawah rezim Donald Trump dan arah kebijakan Luar Negeri dalam bidang keamanan maupun ekonomi sekarang sangat sulit ditebak, yang juga berpengaruh terhadap kemajuan ASEAN. Tulisan ini bertujuan untuk menganalisa arah kebijakan Luar Negeri Donald Trump dan mengkaitkannya dengan kerjasama Amerika Serikat-ASEAN.
\end{abstract}

Kata Kunci: amerika serikat; kebijakan luar negeri; donald trump; rezim; kerjasama.

\section{Abstract}

United States is state which gives impact on cooperation with ASEAN (Association of Southeast Asia Nations). It's foreign policy influence international rezime. The direction of United States foreign policy which is determined by chosen President also influence ASEAN region in which most of the member states are potential for international market. Indonesia, Malaysia, Singapore, or The Philipines are examples which are influenced by Unites States's foreign policy. In the Donald Trump rezime, it is hard to predict United States's foreign policy. It becomes a challenge for ASEAN member countries which still reckon on investment and cooperation with developed states like United States. Alliance with the United States under rezime of Donald Trump and its foreign policy in the security and economy is hard to be predict, which then influence ASEAN advancement as a regional organization. This research is aim to analyze United States's foreign policy under rezime of Donald Trump and correlate it with cooperation between Unites States-ASEAN.

Keywords: united states; foreign policy; donald trump; regime; cooperation.

\section{Pendahuluan}

Amerika Serikat merupakan negara adidaya yang terus ingin membangun dan mempertahankan pakta pertahanan baik di bidang ekonomi maupun militer di dunia. Amerika Serikat semakin memperkuat kerjasamanya dalam berbagai bidang, salah satunya adalah dengan menjalin kerjasama dengan ASEAN (Association of Southeast Asian Nations). ASEAN merupakan regional di Asia Tenggara yang memiliki 10 negara anggota (Indonesia, Malaysia, Singapura, Brunei Darussalam, Myanmar, Laos, Kamboja, Vietnam, Filipina, dan Thailand) yang didirikan pada tanggal 8 Agustus 1967 di Bangkok, Thailand.

Amerika Serikat sebagai salah satu negara maju di dunia tidak ingin menyianyiakan kesempatan untuk mempertahankan kedudukannya di dunia dengan menunjukkan adanya kekuatan di bidang militer dan ekonomi. Pasca perang dingin, negara-negara di dunia ramai-ramai mencari negara yang bisa 
106 Dwi Ardiyanti Imprediktabilitas Kebijakan Luar Negeri Amerika Serikat: Tantangan Dan Ancaman Rezim Donald

dijadikan poros kekuatan untuk menangkal ancaman bom nuklir dari Rusia. Dalam unipolaritas, Amerika menemukan sebuah cara untuk mempertahankan perdamaian dunia yaitu dengan menjadi penyeimbang kekuatan dan menyebarkan asas demokrasi. Di saat yang sama, Amerika juga mempertahankan kekuatannya di poros dunia sebagai satusatunya negara pemenang peran yang memiliki kekuatan untuk mengendalikan dunia. ${ }^{1}$ Unipolaritas yang dibangun oleh Amerika Serikat merupakan salah satu cara untuk mempertahankan hegemoninya di dunia baik dalam bidang ekonomi, politik, maupun keamanan.

Seperti yang dijelaskan oleh Jeff Legro bahwa unipolaritas selalu dilakukan dengan beberapa media, antara lain organisasi internasional, ketergantungan ekonomi, persepsi ancaman, bahaya nuklir, institusi domestik $^{2}$, Amerika berusaha mempertahankan hegemoninya dengan bekerjasama dengan organisasi regional, salah satunya adalah ASEAN.

Kerjasama yang dijalin Amerika Serikat dengan beberapa negara maupun institusi kawasan hanya salah satu dari banyak cara untuk mengendalikan dunia. Dalam kasus negara Indonesia, misalnya, kerjasama dalam bidang pertambangan emas Freeport sangat bergantung pada Amerika Serikat selama bertahun-tahun. Hubungan Indonesia Amerika Serikat sampai saat ini masih dikatakan menjalin hubungan baik. Dengan adanya ketergantungan ekonomi salah satu negara ASEAN dengan Amerika, maka posisi Amerika Serikat di kawasan Asia Tenggara masih diperhitungkan.

Kerjasama antara Indonesia dan
Amerika dalam bidang eksplorasi dan
pengolahan emas

\footnotetext{
${ }^{1}$ John G.Ikenberry, et.a.l. International Relations Theory and The Consequences of Unipolarity. (Cambridge: Cambridge University Press. 2009). p.29

${ }^{2}$ Dalam buku International Relations Theory and The Consequences of Unipolarity
}

Papua) yang merupakan sumber daya alam Indonesia, membuat Amerika secara ekonomi diuntungkan, yaitu dengan adanya kepastian stok emas untuk Amerika. Hal ini akan membuat posisi Amerika sebagai negara yang kuat secara ekonomi makin diakui. Bagi Amerika, sangat penting untuk mencitrakan diri sebagai negara yang kuat, agar dapat menarik minat negara anggota ASEAN bekerjasama dengan Amerika Serikat.

Secara geopolitik, kerjasama dengan ASEAN menguntungkan. Sebagian besar negara anggota ASEAN merupakan negara yang berada di wilayah strategis untuk akses perdagangan internasional jika dilihat dari potensi kekayaan alam dan geografisnya. Selain itu, kawasan ASEAN merupakan pasar potensial untuk pemasaran produk asing, salah satunya dari Amerika. Negara anggota ASEAN masih terus dibayangi ketakutan akan nuklir yang aktif dijadikan alat ancaman oleh Korea Utara maupun Rusia. Oleh karena itu, Amerika Serikat bertindak sebagai negara yang mampu memberikan rasa aman jika bekerjasama dengan negara anggota ASEAN. Di sisi lain, peran Amerika sebagai negara adikuasa juga harus memperkuat eksistensinya, misalnya demi mempertahakan kepentingannya di Laut Tiongkok Selatan yang masih berkonflik baik antara negara anggota ASEAN sendiri maupun dengan negara yang berkepentingan di dalamnya. ${ }^{3}$ Amerika diduga memiliki kepentingan tertentu di Laut Tiongkok Selatan sehingga menjalin kerjasama dengan negara anggota ASEAN yang ikut terlibat dalam konflik tersebut. ${ }^{4}$

Masih dalam kacamata keamanan internasional, Amerika melihat adanya ancaman di bidang keamanan yang besar datang dari negara Tiongkok yang tidak lagi

\footnotetext{
${ }^{3}$ Abdul Musyawardi Chalid, dkk. "Peran Asean Merespons Kerja Sama Militer Amerika Serikat dan Filipina Terkait Konflik Laut CinaSelatan". Intermestic:Journal oflinternational Studies. No1(2016). p 4

${ }^{4}$ Ibid. p. 5
} 
107 Dwi Ardiyanti Imprediktabilitas Kebijakan Luar Negeri Amerika Serikat: Tantangan Dan Ancaman Rezim Donald

sungkan memperluas kekuatannya di wilayah Asia. Melihat hal ini Amerika tidak ingin melepaskan kendalinya begitu saja di wilayah Asia Tenggara dan di saat yang sama merupakan media penyeimbang posisi Tiongkok di Asia. Amerika juga mulai melihat adanya kekuatan potensial yang ditunjukkan oleh Republik Rakyat Tiongkok di wilayah ASEAN. ${ }^{5}$

ASEAN juga memiliki posisi penting dalam percaturan perekonomian dunia sebagai salah satu kawasan pasar internasional di dunia. Sebagian besar negara anggota ASEAN potensial sebagai pasar internasional, terutama dalam bidang ekonomi. Dengan melihat bahwa sebagian besar negara anggota ASEAN (Malaysia, Singapura, Brunei Darussalam, Vietnam, Filipina) masih terus saling berkonflik dalam isu Laut Tiongkok Selatan, maka kepentingan dan kebergantungan atas Amerika masih terus berjalan, yaitu sebagai penyeimbang kekuaran dari Tiongkok, Korea Utara, Jepang, maupun Rusia, ${ }^{6}$ mengingat negara-negara tersebut memiliki nuklir.

Salah satu bentuk penyeimbangan kekuatan oleh Amerika Serikat adalah dengan cara demokratisasi Myanmar pada masa Aung San Suu Kyi di Myanmar ${ }^{7}$. Myanmar yang merupakan salah satu negara anggota ASEAN masih belum mampu secara maksimal mengelola konflik di negaranya sendiri dengan baik. Hal ini dikarenakan adanya keterlibatan negara lain dalam kepentingan terhadap Myanmar dengan kepala negara Aung San Suu Kyi.

Hal ini sesungguhnya merupakan 'cambuk' bagi ASEAN sebagai sebuah entitas

\footnotetext{
${ }^{5}$ Ibid. p.9

${ }^{6}$ A New Balance of Power in Asia: Japan and U.S.; China and Russia; India and ASEAN. https://www.huffingtonpost.com/chenxiangyang/new-asia-balance-ofpower_b_6116198.html, diakses pada 17 Oktober 2017

${ }^{7}$ President Obama and Aung San Suu Kyi Celebrate Progress in Burma.September 15, 2016 at 7:14 PM ET by Grace Aranow
}

organisasi regional yang masih terkendala dengan prinsip non-intervention namun belum mampu menyelesaikan konflik di kawasannya sendiri. Oleh karena itu, campur tangan negara lain seperti Amerika merupakan salah satu alasan kurang efektifnya pengelolaan konflik dengan baik, oleh negara maupun organisasi regional.

Dalam kasus konflik Laut Tiongkok Selatan, Filipina dan Indonesia dan beberapa negara anggota ASEAN lain masih terus menjalin kerjasama yang baik dengan Amerika Serikat. Selain itu, ASEAN memiliki pekerjaan rumah yang besar yaitu menghilangkan campur tangan Amerika dalam penyelesaian konflik di Laut Tiongkok Selatan. Selaku entitas organisasi regional di Asia Tenggara, ASEAN harus dapat menyeleraskan suara demi tercapainya motto ASEAN yaitu One Identity, One Vision, One Community. Resolusi konflik oleh ASEAN belum dapat secara optimal mengelola konflik yang terjadi didalamnya. Berikut ini adalah penjelasan tahapan penyelesaian konflik oleh organisasi regional.

Langkah yang ditempuh oleh organisasi regional dalam penyelesaian konflik,antara lain Confidence Building Measures (CBM) yaitu bagaimana pihak-pihak terkait berupaya mengurangi ketegangan dengan tujuan untuk mencari penyelesaian dan sebagai langkah yang paling bergunauntuk membuka jalan terhadap perjanjian yang lebih komprehensif, preventive diplomacy berupa tindakan-tindakan kolektif yang dilakukan untuk pencegahan awal konflik yang terdiridari kumpulanaksi diplomasi, politik, militer, ekonomi, dan kemanusiaan. Sedangkan Conflict Resolution merupakan upaya lebih jauh setelah kedua upaya awal telah dilakukan. $^{8}$

Sejak dulu sebagian besar negara anggota ASEAN masih mengandalkan kerjasama dari negara maju, salah satunya adalah kerjasama dengan negara Amerika Serikat. Kepentingan Amerika Serikat untuk

\footnotetext{
${ }^{8}$ Op. Cit. p. 18
} 
108 Dwi Ardiyanti Imprediktabilitas Kebijakan Luar Negeri Amerika Serikat: Tantangan Dan Ancaman Rezim Donald

Trump Terhadap Asean

mencegah semakin besarnya kekuatan Republik Rakyat Tiongkok di wilayah Asia Timur dan ASEAN membuat Amerika Serikat harus terus menggalakkan kerjasama untuk mengimbangi kekuatan Tiongkok di ASEAN. ${ }^{9}$ Segala bukti di atas menyimpulkan keberlanjutan peran Amerika menjadi penyeimbang kekuatan dunia dari Rusia, Tiongkok, Jepang, bahkan Korea Utara ${ }^{10}$. Namun, setelah terpilihnya Donald Trump sebagai presiden Amerika Serikat terdapat banyak kebijakan Luar Negeri yang kontroversial. Salah satunya adalah kebijakan Luar Negeri menjalin kerjasama dengan Myanmar. Aung San Suu Kyi yang kini lebih memilih menjalin kerjasama dengan Tiongkok dan Rusia dibanding Amerika ${ }^{11}$ merupakan salah satu contoh adanya ketidakpastian kebijakan Luar Negeri Amerika pasca terpilihnya Donald Trump sebagai Presiden Amerika. Tidak seperti pendahulunya, Obama, Donald Tump justru mengesampingkan peran penting di Myanmar sebagai salah satu negara anggota ASEAN yang ingin mendukung demokratisasi Amerika di wilayah Asia Tenggara sehingga ancaman terhadap kesiasiaan usaha demokratisasi oleh pendahulunya dan ancaman penyebaran komunisme di Asia tepat berada di depan mata Amerika. Di PBB, Tiongkok telah menggunakan hak veto menolak rencana pasukan PBB untuk menangani konflik mengarah ke genocide di Myanmar. Aung San Suu Kyi lebih memilih mengandalkan Tiongkok dan Rusia ${ }^{12}$ dibanding Amerika pasca terpilihnya Donald

\footnotetext{
${ }^{9}$ Ibid. p. 17

${ }^{10}$ A New Balance of Power in Asia: Japan and U.S.; China and Russia; India and ASEAN https://www.huffingtonpost.com/chenxiangyang/new-asia-balance-ofpower_b_6116198.html diakses pada 17 Oktober 2017

${ }^{11}$ Myanmar working with China, Russia, to avoid UN rebuke over persecution of Muslims http://www.businessinsider.com/myanmarworking-with-china-russia-to-avoid-un-rebukeover-persecution-of-muslims-2017-9/?IR=T diakses pada 17 Oktober 2017

${ }^{12}$ Ibid
}

Trump sebagai presiden Amerika Serikat. Selain itu, beberapa kebijakan Luar Negeri yang diambil oleh Donald Trump yang berbeda dari para presiden Amerika Serikat sebelumnya.

Hal ini sangat menarik untuk diteliti, mengingat karakter Donald Trump yang kontroversial. Langkah Donald Trump tentu akan berpengaruh terhadap berbagai kebijakan Luar Negeri, salah satunya adalah pengaruhnya terhadap kerjasama Amerika-ASEAN. Sebagai organisasi regional yang merupakan mitra kerjasama Amerika, ASEAN juga harus melihat dengan cermat imprediktabilitas kebijakan Luar Negeri Amerika sebagai ancaman atau bahkan tantangan bagi ASEAN sendiri. Para pemegang kekuasaan baik di tingkat negara anggota maupun di tingkat regional ASEAN harus jeli melihat arah kebijakan Luar Negeri Amerika dan mengambil sikap cermat untuk merencanakan masa depan ASEAN. Penelitian ini mengangkat permasalahan tentang "Bagaimana ketidakpastian rezim Donald Trump berpengaruh terhadap kerjasama Amerika Serikat-ASEAN?"

\section{Tujuan Penelitian}

Penelitian ini bertujuan untuk memperdalam kajian ilmu politik Luar Negeri Amerika Serikat di bawah rezim Donald Trump yang berfokus pada pola kepemimpinan Donald Trump di percaturan politik dunia menjadi hal yang tidak dapat diprediksi (unpredictable). Di sisi lain, gaya kepemimpinan yang diusung tanpa memiliki latar belakang dibidang politik, membuat isu pribadi yang kontroversial dari Donald Trump berlatar belakang sebagai konglomerat dan pebisnis dunia menjadi penggambaran yang berbeda dari para pendahulunya, para presiden Amerika sebelumnya. Hal ini juga menjadi penting ketika mengkorelasikannya dengan penggambaran negara lain kepada Amerika di masa kepemimpinan Donald Trump. 
109 Dwi Ardiyanti Imprediktabilitas Kebijakan Luar Negeri Amerika Serikat: Tantangan Dan Ancaman Rezim Donald

\section{Kontroversi Pengaruh Amerika Bidang Keamanan dan Ekonomi di ASEAN Pada Rezim Donald Trump}

Salah satu daya tarik negara berkembang untuk menjalin kerjasama dengan Amerika Serikat adalah kekuatan ekonomi dan tawaran bantuan militer negara Amerika terhadap negara yang bekerjasama dengannya. Faktor ekonomi dan militer merupakan kekuatan penting dalam bidang politik dunia.

Kerjasama antara ASEAN dan Amerika Serikat telah dimulai sejak tahun $1977^{13}$. Kemudian sejak tahun 2009 kerjasama tersebut difokuskan dengan bebeapa prioritas kerjasama, yaitu bidang Politik dan Keamanan:

1) Kejahatan lintas negara, termasuk Counter Terrorism, 2) Capacity Building for Good Governance, the Rule of Law and Judiciary Systems Human Rights promotion;3)Ekonomi; Ecomomy Programs, 4) Finance Cooperation: Sosial Budaya;5) Science and Technology; Disaster Management; Environment, 6)Climate Change, 7)Food and Energy Security; 8) Education Including Scolarship and Training Programs.

Kerjasama berlangsung begitu baik dengan kelanjutan kerjasama yaitu ditandatanganinya Plan of Action berlaku lima tahunan (2006-2011) pada bulan Desember 2016. Amerika semakin banyak menjalin kerjasama dengan negara berkembang di wilayah Asia dengan tujuan memperluas pasar internasional dan mengembangkan kekuatan sebagai poros dunia. Beberapa contoh kerjasama dengan Amerika Serikat antara lain, ekonomi (investasi maupun hutang negara), bidang keamanan (bantuan pasukan, senjata, militer), pendidikan (beasiswa, penelitian), sosial budaya (pertukaran budaya), maupun dalam bidang transfer kecanggihan teknologi. ${ }^{14}$ Sebaliknya, Amerika juga mendapat keuntungan dari kerjasama yang ditawarkan negara berkembang tersebut, diantaranya,

\footnotetext{
${ }^{13}$ Kerjasama ASEAN dan Mitra Wicara.pdf.

${ }^{14}$ VOA Indonesia.com: RI-AS Pererat Kerjasama dalam Berbagai Bidang
}

menjadi pasar bagi produk Amerika Serikat, menyediakan bahan baku mentah. Dengan diawali kerjasama bidang ekonomi dan politik, sebagai modal penting bagi negara, maka akan lebih mudah bagi Amerika Serikat untuk membangun pakta pertahanan keamanan dan ekonomi di wilayah Asia.

Masalah keamanan di Laut Tiongkok Selatan merupakan salah satu indikator stabilitas keamanan kawasan Asia-Pasifik. ${ }^{15}$ Kebijakan Luar Negeri Amerika di bawah rezim Donald Trump juga perlu dipertanyakan dengan terjalinnya kerjasama Amerika dengan Vietnam dan Filipina sementara Myanmar dan Kamboja cenderung memihak Tiongkok, menambah kompleksitas keamanan regional di kawasan. Di sisi lain, Malaysia yang terlibat di dalam sengketa ini termasuk kedalam koalisi Five Power Defence Arrangements (FPDA). ${ }^{16}$

Seperti diketahui, konflik antar negara anggota ASEAN dalam masalah Laut Tiongkok Selatan juga belum diselesaikan meski sudah diadakan beberapa kali KTT ASEAN yang mengagendakan penyelesaian konflik Laut Tiongkok Selatan. Beberapa strategi ASEAN yang bisa diterapkan sebagai sebuah organsiasi regional dalam menangani konflik di Asia Tenggara antara lain: norm setting, assurance, community-building, deterrence, non-intervention, isolation, intermediation, enforcement and internationalization. $^{17}$

Amerika yang menjalin kerjasama erat dengan Filipina masih memberikan bantuan finansial dan militer kepada negara tersebut. Filipina yang ketika itu menjadi negara tuan rumah terselenggaranya KTT ASEAN, persetujuan yang ditaati ketika KTT bahkan memasukkan persetujuan dari Amerika. ${ }^{18}$

\footnotetext{
${ }^{15}$ Op.Cit. p. 17

${ }^{16}$ Ibid. p. 11

${ }^{17}$ Regional Security in Southeast Asia_Beyond the ASEAN Way by Mely Caballero-Anthony.pdf

${ }^{18} 5$ catatan penting KTT ASEAN 2015 https://www.rappler.com/indonesia/113775-kttasean-summit-2015 diakses pada 17 Oktober 2017
} 
110 Dwi Ardiyanti Imprediktabilitas Kebijakan Luar Negeri Amerika Serikat: Tantangan Dan Ancaman Rezim Donald

Bantuan Amerika ke Filipina terus bertambah, bahkan intensitasnya diprediksi semakin besar tiap tahunnya. Padahal, keterlibatan pihak eksternal dalam sengketa Laut Tiongkok Selatan berpotensi menciptakan eskalasi konflik yang lebih besar yang pada akhirnya dapat mengancam implementasi APSC (ASEAN Political Security Community). ${ }^{19}$

Namun, pada rezim Donald Trump, arah kebijakan Luar Negeri sedikit menyiratkan hubungan 'tidak harmonis' antara Amerika Serikat dan Filipina. Seperti yang dijelaskan di atas, bahwa Filipina lebih memilih untuk bekerja sama dengan Amerika. Pada masa pemerintahan Donald Trump, Duterte sebagai presiden Filipina tidak lagi berniat untuk bekerja sama dengan Amerika. Hal yang menarik adalah ketika Duterte menyatakan tidak ingin terlalu bergantung dengan aliansi Amerika. ${ }^{20}$ Dengan absennya penyeimbangan kekuatan Amerika di ASEAN, Filipina kini juga lebih tertarik untuk bekerja sama dengan Tiongkok. Salah satu contohnya adalah dalam kasus Laut Tiongkok Selatan yang melibatkan Filipina di dalamnya.

Trump adalah sosok yang kontroversial baik di dunia maya maupun di dunia nyata. Beberapa pernyataan Trump sebagai presiden Amerika sempat memanaskan keadaan dengan Tiongkok. Berkebalikan dengan kondisi ketika dipimpin oleh Obama, kedekatan antara Amerika Serikat dan Filipina berjalan baik. Justru, langkah Obama dianggap sebagai sebuah kegagalan oleh Donald Trump ${ }^{21}$.

“...Trump argued that U.S. foreign policy in the post-Cold War era had been wasteful,

\footnotetext{
${ }^{19}$ Op. Cit. p. 18

${ }^{20}$ America, Not Duterte, Failed the Philippines http://nationalinterest.org/feature/america-notduterte-failed-the-philippines-20195 diakses pada 17 Oktober 2017

${ }^{21}$ What Will Donald Trump's Asia Policy Look Like _ The Diplomat.htm diakses pada 11 Juli 2017
}

\begin{abstract}
rudderless, unreliable, and ineffective. By contrast, Trump said he would focus more narrowly on rebuilding America's military and economy, curbing the spread of radical Islam, and fashioning what he called a "new rational American foreign policy," which some have also since somewhat loosely termed a version of realism". ${ }^{22}$
\end{abstract}

Dari kutipan pidatonya setelah terpilih menjadi Presiden Amerika Serikat, Trump menyatakan bahwa arah kebijakan Luar Negeri Amerika Serikat pasca Perang Dingin sudah tidak bisa lagi diterapkan sekarang. ${ }^{23}$ Trump akan lebih berfokus pada kerjasama militer dan ekonomi dan memerangi tindakan radikalisme Islam dan membentuk kebijakan Luar Negeri dengan gaya baru yang disebut degan "new rational American foreign policy" yang merupakan gaya realisme dengan versi terbaru. Amerika dibawah rezim Donald Trump melakukan halhal yang sulit diprediksi oleh dunia. Salah satunya adalah faktor karakteristik Donald Trump dan sudut pandangnya yang kontras dengan para pendahulunya. Trump lebih menekankan pada kebijakan Luar Negeri di bidang keamanan dan militer, yang juga menjadi fokus kerjasama bagi negara anggota ASEAN.

Faktor pendukung utama terjalinnya kerjasama ekonomi dengan negara lain adalah kekuatan ekonomi negara Amerika Serikat. Hubungan negara Amerika Serikat-ASEAN telah lama terjalin. Namun dengan gaya kepemimpinan Donald Trump, Amerika menjadi lebih realis dan menekankan pendekatan self-interested dalam menjalin kerjasama di bidang ekonomi dan militer. Sementara ASEAN menginginkan mitra kerjasama yang bisa membentenginya dari ancaman nuklir dari Korea Utara, Rusia,
${ }^{22}$ Ibid

${ }^{23}$ Ibid 
111 Dwi Ardiyanti Imprediktabilitas Kebijakan Luar Negeri Amerika Serikat: Tantangan Dan Ancaman Rezim Donald

Jepang, Tiongkok, dan juga mendambakan negara adikuasa yang mampu menciptakan iklim stabil bagi perkembangan ekonomi. Hal ini tampaknya tidak terlihat dari Amerika di masa kepemimpinan Donald Trump.

$$
\text { “...two of Trump's advisers, }
$$
Alexander Gray and Peter Navarro, framed Trump's Asia approach - which would involve a more self-interested approach to economics and a stronger military - almost entirely around China's rising assertiveness and Beijing's overplaying of its hand in the region. The piece, which also blamed the Obama administration for failing to respond to Chinese gains in the South China Sea as well as with America's twin Southeast Asian allies, Thailand and the Philippines, was far more hawkish than what we have seen in U.S.-China policy in recent years....he said the United States would now "work closely" with the institution on that challenge since, following his criticism on its obsolescence, NATO had shown a willingness to change by having a new division focused on terror threats ${ }^{3}{ }^{24}$.

Di atas telah disebutkan bahwa Amerika selalu memposisikan dirinya sebagai penyeimbang kekuatan dari Tiongkok, Rusia, Jepang, dan Korea Utara, namun pada masa kepemimpinan Donald Trump terlihat ada yang berbeda dari arah kebijakan Luar Negeri Amerika yang cenderung melonggarkan aliansinya dengan Jepang, salah satu alasan penyeimbang kekuatan karena kepemilikan nuklirnya. Namun, ketika Trump terpilih

\footnotetext{
${ }^{24}$ What Will Donald Trump's Asia Policy Look Like _ The Diplomat.htm diakses pada 11 Juli 2017
}

sebagai Presiden Amerika Serikat, Trump menekankan kerjasama dalam bidang keamanan dengan Jepang. Donald Trump justru lebih 'melonggarkan' aturannya terhadap negara Jepang. Amerika yang tadinya merasa Jepang adalah negara yang patut untuk diwasapadai dengan kepemilikan nuklirnya, ketika kepemimpinan Trump akan mengambil tindakan untuk mentoleransi program nuklir yang ada di Jepang dan menarik pasukan Amerika Serikat di Jepang. Amerika juga akan membuka kesempatan kerjasama dengan Korea Utara dengan rencana membuka diskusi awal demi menghadapi ancaman nuklir ke depan. ${ }^{25}$ Kerjasama Luar Negeri Amerika dengan negara-negara pemilik nuklir bisa menjadi tantangan atau bahkan ancaman dalam menjaga keamanan dunia.

Tindakan ini tentu sangat kontroversial dengan pemerintahan Amerika sebelumnya yang memerangi negara-negara yang memiliki nuklir dan menjadikan Amerika sebagai polisi dunia. Donald Trump ingin memulai untuk membuka diskusi dengan negara-negara yang dianggap mengancam dunia karena memiliki nuklir. Dari sudut pandang kemanan wilayah ASEAN, langkah yang diambil oleh Donald Trump ini memiliki tantangan tersendiri. Wacana untuk membuka diskusi dengan negara pemilik nuklir membuat ancaman baru dengan adanya keberpihakan Amerika di balik proyek nuklir yang tadinya menjadi ancaman dunia, terutama bagi negara anggota ASEAN.

Namun di sisi lain, jika kebijakan Luar Negeri ini dilihat dari kacamata anti hegemoni, langkah Donald Trump justu memberikan sebuah optimisme tersendiri bahwa Amerika tidak lagi bertindak dengan hegemoninya sebagai polisi dunia. Termasuk didalamnya, tantangan keamanan yang datang di saat yang sama ketika Amerika justru menunjukkan kontestasi kepemilikan nuklir. Selanjutnya, hal ini juga akan menjadi perbandingan bagi

${ }^{25}$ Ibid 
112 Dwi Ardiyanti Imprediktabilitas Kebijakan Luar Negeri Amerika Serikat: Tantangan Dan Ancaman Rezim Donald Trump Terhadap Asean

Tiongkok untuk mempertahankan kekuatannya di wilayah Asia. Tidak ada yang pasti dalam kebijakan Luar Negeri pada rezim Donald Trump.

\section{Aksi Counter Terorism Amerika di ASEAN pada Era Rezim Donald Trump}

Keberpihakan Amerika ke negaranegara pemilik tenaga nuklir dengan alasan menjaga keamanan dunia merupakan salah satu langkah yang mengejutkan. Berbeda dari para pendahulunya, Donald Trump justru memilih jalan yang tidak terduga.

Amerika di sisi keamanan masih ingin menjadi polisi dunia, namun dengan jalan membagi peran dengan negara pemilik nuklir. Sehingga, negara lain yang tadinya bergantung pada Amerika untuk mengatasi ketakutan akan nuklir, menjadi bingung dengan kebijakan Luar Negeri Amerika Serikat.

Fokus pada aksi anti terorisme dan keamanan merupakan dua hal penting yang dikedepankan Amerika Serikat dalam menjalin kerjasama Luar Negeri, yaitu kebijakan Counter Terrorism. Di bawah rezim Donald Trump sekarang, praktek Counter Terrorism semakin menemui ketidakpastian ketika secara jelas justru Amerika bekerjasama dengan negara pemilik nuklir namun mempertunjukkan kebijakan Donald Trump yang memerangi pemeluk Islam tak terkecuali bagi penduduk Amerika Serikat. Di era Obama, Amerika sangat peduli dengan multikulturalisme. Bukan dengan memerangi penduduk Islam, Obama lebih mempertunjukan bantuan ke negara Suriah untuk memerangi ISIS. ${ }^{26}$ Namun, Trump justru menekankan kerjasama dengan negara-negara yang dulunya menjadi 'musuh' bagi Amerika, yaitu kerjasama dengan Tiongkok dan Rusia untuk memerangi

\footnotetext{
${ }^{26}$ The Guardian. America dropped 26,171 bombs in 2016. What a bloody end to Obama's reign

https://www.theguardian.com/commentisfree/2017/j an/09/america-dropped-26171-bombs-2016-obamalegacy diakses pada 17 Oktober 2017
}

tindakan terorisme. Trump juga memerangi terorisme dengan menyebarkan sikap dan pernyataan arogansinya yang menolak pemeluk agama Islam.

".And with respect to Trump's
willingness to work with
authoritarian countries like
Russia and China, Trump has
repeatedly said that this is due not
to his ideological leanings, but
simply because he views the
challenge of radical Islam as
being far more important and
urgent. And with respect to
Trump's willingness to work with
authoritarian countries like
Russia and China, Trump has
repeatedly said that this is due not
to his ideological leanings, but
simply because he views the
challenge of radical Islam as
being far more important and
urgent". 27 a

Negara Rusia dan Tiongkok yang dikenal sebagai negara komunis dan antidemokratisasi menjadi sasaran selanjutnya bagi Amerika Serikat untuk menjalin kerjasama dalam menangani aksi terorisme. Yang menarik untuk dikaji adalah tantangan di rezim Donald Trump yang tidak pilih kasih untuk bekerjasama dengan negara dengan basis militer non-demokrasi dengan kepemilikian nuklir yang kuat di dunia. Dengan kata lain, Amerika tidak lagi ingin menduduki posisi sebagai poros dunia dalam bidang keamanan, namun ingin menjaga keamanan dunia bersama dengan negara yang maju di bidang ekonomi dan militer meski mempertaruhkan kontestasi yang selama ini ditunjukkan oleh pemimpin Amerika Serikat yang sebelumnya. Tentu, hal ini menjadikan ancaman dan tantangan dunia

\footnotetext{
${ }^{27}$ What Will Donald Trump's Asia Policy Look Like _ The Diplomat.htm diakses pada 11 Juli 2017
} 
113 Dwi Ardiyanti Imprediktabilitas Kebijakan Luar Negeri Amerika Serikat: Tantangan Dan Ancaman Rezim Donald

menjadi semakin tidak jelas ketika yang menjadi 'polisi dunia' kini tidak lagi menjadi 'penyeimbang' kekuatan dalam percaturan keamanan dunia, namun lebih mengedepankan cara tersendiri untuk mengurusi isu terorisme dan keamanan dunia. Bagi ASEAN kebijakan Luar Negeri Donald Trump dalam memerangi terorisme merupakan ancaman nyata, terutama bagi negara dengan kekuatan keamanan yang kurang. Upaya balance of power makin sulit dilakukan jika semua negara maju dalam bidang ekonomi dan keamanan menjadi satu sekutu aktif yang siap untuk meluluhlantahkan dunia.

\section{Rezim Donald Trump dan Kerjasama dengan ASEAN}

Upaya Amerika untuk menjalin kerjasama dengan organisasi regional seperti ASEAN didasarkan pada kepentingan kemanan, militer dan ekonomi. Amerika di bawah rezim Donald Trump serius dalam menangani gerakan radikalisme dan terorisme. Dalam konteks kerjasama dengan ASEAN, Trump memperlihatkan sikap kontranya dengan langkah yang diambil oleh pendahulunya, Obama.

“...On regional institutions and multilateralism more generally, there are very few indications of what Trump's views are. The temptation would be to assume that if he has very little patience even for free-riding allies, then he would devote almost none of America's attention to Asian multilateral engagements led by the Association of Southeast Asian Nations (ASEAN), a sharp contrast to the Obama administration, which had devoted more time, attention, and resources to ASEAN-led institutions" (See: "Why the US-

\section{ASEAN Sunnylands Summit Matters"). ${ }^{28}$}

Trump menyatakan bahwa tidak terlalu menginginkan kerjasama dengan organisasi regional seperti ASEAN. Hal ini sangat kontradiktif dengan yang dilakukan oleh Obama yang terus melakukan pendekatan dengan organisasi regional ASEAN karena dipandang sangat potensial untuk bekerjasama dalam bidang ekonomi. Namun Trump seperti tidak ingin terus melanjutkan paradigma dari pendahulunya yaitu ingin menjadi penguasa dunia dan menjadikan Amerika sebagai pemimpin gerakan ekonomi dunia. "I am not running to be president of the world," Trump said to emphasize his point. "I am running to be president of the United States, and that's what we're going to take care of". ${ }^{29}$

Dalam beberapa tahun terakhir Tiongkok semakin meningkatkan ketahanan ekonomi dan militernya untuk mengimbangi posisinya di Asia menghadapi hegemoni Amerika. Stabilitas perdamaian dan keamanan di wilayah Asia akan terus menghadapi tantangan dari negara Tiongkok, misalnya Taiwan (yang telah lama mendapat bantuan Amerika dalam menghadapi tekanan dari Tiongkok), negara Asia yang lain seperti Jepang, Singapura, Vietnam, Malaysia, Indonesia, Filipina dan India masih terus membuka diri untuk kerjasama strategis dengan Amerika. ${ }^{30}$

Namun, dengan melihat arah kebijakan Luar Negeri Amerika, negara seperti Filipina tampak tidak lagi ingin mendapatkan bantuan dari Amerika namun lebih memilih ke kubu Tiongkok. ${ }^{31}$ Semakin besarnya kekuatan

\footnotetext{
${ }^{28}$ What Will Donald Trump's Asia Policy Look Like _ The Diplomat.htm diakses pada 11 Juli 2017

${ }^{29}$ Ibid

${ }^{30}$ John G. Ikenberry. Op.Cit. p. 146

${ }^{31}$ Duterte: "Bye Bye America, We Don't Need Your Money, China Said They Will Provide"
} 
114 Dwi Ardiyanti Imprediktabilitas Kebijakan Luar Negeri Amerika Serikat: Tantangan Dan Ancaman Rezim Donald Trump Terhadap Asean

Tiongkok di wilayah Asia, menyiratkan kegagalan upaya penyeimbangan kekuatan Amerika di Asia, terutama pada masa kepemipinan Donald Trump. Trump ingin menunjukkan caranya sendiri dalam memimpin Amerika, meskipun dalam beberapa hal sangat berkebalikan dengan para pendahulunya yang tidak hanya ingin menjadi polisi dunia namun juga mengklaim negara Amerika Serikat sebagai poros ekonomi dan keamanan dunia. Trump juga tidak terlalu bersemangat untuk menyebarkan isu demokratisasi sebagai idealisme terbaik di dunia demi mencapai perdamaian dunia "...universal values that not everybody shares or wants, but will instead work with U.S. allies to reinvigorate Western values and institutions". ${ }^{32}$

Ketidakpastian rezim Donald Trump membuat persepsi negara lain tidak tentu. Melihat hal ini, Trump terlihat sangat santai dalam menanggapi respon dunia tentang kebijakan Luar Negeri Amerika Serikat di bawah kepemimpinannya. Kecenderungan aliansi dan tujuan negara tidak lagi sama dengan pemimpin Amerika Serikat yang sebelumnya. Selain itu, Trump juga memiliki langkah tersendiri menanggapi keresahan dunia mengenai kecenderungan aliansi negara di bawah rezim Trump.

\section{Ketidakpastian Arah Kebijakan Amerika di bawah Rezim Trump}

Dalam pandangan para politikus negara, Trump tidak hanya berbeda dari pendahulunya, namun juga memiliki pesan tersendiri di setiap kebijakan yang diambilnya. Hal ini semakin menegaskan ketidakpastian arah kebijakan

http://www.zerohedge.com/news/2016-1217/duterte-bye-bye-america-we-dont-need-yourmoney-china-said-they-will-provide diakses pada 17Oktober 2017

${ }^{32}$ What Will Donald Trump's Asia Policy Look Like _ The Diplomat.htm diakses pada 11 Juli 2017
Luar Negeri Amerika di bawah rezim Trump, seperti pernyataannya berikut ini:

\begin{abstract}
"We must as a nation be more unpredictable. We are totally predictable. We tell everything. We're sending troops? We tell them. We're sending something else? We have a news conference. We have to be unpredictable," Trump said, waving his index finger in the air to make the point. "And we have to be unpredictable starting now. ${ }^{133}$
\end{abstract}

Trump menjanjikan bahwa di bawah kepemimpinannya, pola yang selama ini diikuti akan berakhir.Masalah bagaimana dia melakukannya adalah sebuah misteri. Tidak ada dimensi pandangan dari Donald Trump, tidak ada pidato yang pernyataan yang akan mendukung anti-multilateralis. Contohnya, Trump berulang kali mengulangi pernyataan tentang sistem adiministrasi politik yang korup, yang mengagungkan globalisme untuk alasan memuaskan diri sendiri, Trump akan berfokus pada apa yang terbaik bagi Amerika. Hal ini sangat berbeda dengan pendahulunya, Obama, yang menyatakan dalam pidatonya bahwa Presiden Amerika Serikat akan memberikan kebebasan dalam kebijakan internasional yang diklaim sebagai sebuah investasi yang tepat dan akan meningkatkan keamanan. ${ }^{34}$

Kebijakan Luar Negeri Amerika di bawah kepemimpinan Trump antimultilateralis akan menimbulkan keraguan bagi negara dengan kultur multilateralisme dengan banyak aliansi. Contohnya, organisasi regional ASEAN yang tidak hanya bekerja sama dengan Amerika sebagai negara maju,

\footnotetext{
${ }^{33}$ Trump Embraces Unpredictability as Foreign Policy Strategy.htm diakses pada 11 Juli 2017 ${ }^{34}$ Ibid
} 
115 Dwi Ardiyanti Imprediktabilitas Kebijakan Luar Negeri Amerika Serikat: Tantangan Dan Ancaman Rezim Donald Trump Terhadap Asean

namun juga dengan negara lain seperti Tiongkok, Korea Selatan dan Jepang $($ Asean+3) maupun dengan negara lain seperti Australia $\left(\right.$ Asean+8). ${ }^{35}$ Amerika di bawah rezim Donald Trump sangat memilih aliansinya dan akan mempertimbangkan untuk bekerja sama hanya dengan negara yang bisa berbagi "beban". Seperti yang dijelaskan di atas, kebijakan Luar Negeri Amerika tidak lagi menganut hegemoni dalam memelihara perdamaian dunia, tapi cenderung berbagi "beban" dengan negara kuat dari sisi militer untuk mengendalikan dunia. Tidak seperti pendahulunya, Amerika yang ingin menjalin kerjasama dengan sebanyak mungkin negara di dunia. Di masa kepemipinan Donald Trump, Amerika terlihat lebih memilih negara sebagai rekan kerjasama sehingga memungkinkan persepsi untuk menimbulkan ancaman dan tantangan di masa depan.

Pertimbangan selanjutnya adalah mengenai posisi Amerika Serikat di bawah rezim Donald Trump yang akan berdiskusi dengan Tiongkok, yang anehnya berada di luar daftar negara aliansi Amerika. Jika dilihat lebih dalam langkah ini diambil untuk melanjutkan "principled security network" di Asia Pasifik, sebuah indikasi yang menunjukkan bahwa Trump akan mengikuti langkah pendahulunya yang memperlakukan Tiongkok dengan cara mencampur kerjasama dan keseimbangan kekuatan. ${ }^{36}$ Keseimbangan peran yang dilakukan Amerika terhadap Tiongkok pada rezim Trump bagi ASEAN menyiratkan peringatan maupun kesempatan kerjasama lain yang terbuka bagi negara anggota ASEAN maupun negara lain yang tadinya menjadi 'musuh'. Trump berusaha mencari jalan yang berbeda untuk menjadi penyeimbang kekuatan di Asia dan dengan cara yang berbeda dari para pendahulunya. Di ASEAN, kebijakan Luar

\footnotetext{
${ }^{35}$ Kerjasama ASEAN dan Mitra Wicara.PDF

${ }^{36}$ What Will Donald Trump's Asia Policy Look Like _ The Diplomat.htm diakses pada 11 Juli 2017
}

Negeri yang dibuat pada masa kepemimpinan Trump menyiratkan adanya ancaman baik di bidang keamanan, militer maupun ekonomi bagi negara-negara anggota ASEAN yang masih berniat menjalin kerjasama dengan Amerika.

\section{Kesimpulan}

Arah kebijakan Luar Negeri Amerika Serikat sangat menentukan baik dari sisi ekonomi, keamanan, sosial, maupun politik dunia. Namun di bawah rezim kepemimpinan Donald Trump yang cenderung berbeda dengan para pemimpin Amerika sebelumnya, membuat negara lain mempertimbangkan ulang kerjasama dengan Amerika Serikat. Termasuk ASEAN yang telah menjalin kerjasama dengan Amerika dalam jangka waktu yang lama. ASEAN tetap ingin melakukan kerjasama dengan Amerika meskipun harus menghadapi tantangan dan ancaman tersendiri bagi negara anggotanya terutama dalam bidang kerjasama ekonomi dan keamanan. Langkah yang diambil oleh Trump dalam kerjasama dengan beberapa negara yang dulu menjadi 'musuh' semakin membuat negara anggota ASEAN sulit untuk memprediksi arah kebijakan Luar Negeri Amerika yang tentunya sangat berhubungan dengan kemajuan negara ASEAN termasuk dalam hal penyelesaian konflik regional Asia Tenggara.

\section{Daftar pustaka}

\section{Buku}

Ikenberry, G John et.a.l. International

Relations Theory and The

Consequences of Unipolarity.

Cambridge: Cambridge University

Press. 2009.

Caballero, Mely. Regional Security in Southeast Asia_Beyond the ASEAN Way.pdf. Singapore : ISEAS Singapore. 2005 
116 Dwi Ardiyanti Imprediktabilitas Kebijakan Luar Negeri Amerika Serikat: Tantangan Dan Ancaman Rezim Donald

Trump Terhadap Asean

Newman, Edward et al. Challenges to Peacebuilding_Managing Spoilers During Conflict Resolution.pdf India: United Nations University Press. 2006

\section{Jurnal}

Chalid, Abdul Musyawardi dkk. Peran Asean Merespons KerjaSama Militer Amerika Serikat Dan Filipina Terkait Konflik Laut Cina Selatan. Intermestic: Journal of International Studies e-issn 2503-443x volume1, no.1, November 2016 (5-22)

Kerjasama ASEAN dan Mitra Wicara.pdf. VOA Indonesia.com: RI-AS Pererat Kerjasama dalam Berbagai Bidang

\section{Artikel}

"President Obama and Aung San Suu Kyi Celebrate Burmese Progress". https://obamawhitehouse.archives.gov/ blog/2016/09/15/president-obama-anddaw-aung-san-suu-kyi-celebrateburmese-progress, diakses pada 25 Juli 2017

"RI-AS Eratkan Kerjasama dalam Berbagai Bidang". https://www.voaindonesia.com/a/ri-aseratkan-kerjasama-dalam-berbagaibidang/1513485.html, diakses pada 25 Juli 2017

"A New Balance of Power in Asia: Japan and U.S.; China and Russia; India and ASEAN", https://www.huffingtonpost.com/chenxiangyang/new-asia-balance-ofpower_b_6116198.html, diakses pada 17 Oktober 2017

Aranow, Grace. President Obama and Aung San Suu Kyi Celebrate Progress in Burma.September 15, 2016 at 7:14 PM ET
"Myanmar working with China, Russia, to avoid UN rebuke over persecution of Muslims", http://www.businessinsider.com/myanmarworking-with-china-russia-to-avoid-unrebuke-over-persecution-of-muslims2017-9/?IR=T , diakses pada 17 Oktober 2017

Kerjasama ASEAN dan Mitra Wicara.pdf. VOA Indonesia.com: RI-AS Pererat Kerjasama dalam Berbagai Bidang

Regional Security in Southeast Asia_Beyond the ASEAN Way by Mely CaballeroAnthony.pdf

5 catatan penting KTT ASEAN 2015, https://www.rappler.com/indonesia/11 3775-ktt-asean-summit-2015, diakses pada 17 Oktober 2017

America, Not Duterte, Failed the Philippines, http://nationalinterest.org/feature/ameri ca-not-duterte-failed-the-philippines20195, diakses pada 17 Oktober 2017

What Will Donald Trump's Asia Policy Look Like _ The Diplomat.htm diakses pada 11 Juli 2017

Duterte: "Bye Bye America, We Don't Need Your Money, China Said They Will Provide", http://www.zerohedge.com/news/2016-1217/duterte-bye-bye-america-we-dontneed-your-money-china-said-theywill-provide, diakses pada 17Oktober 2017

Trump Embraces Unpredictability as Foreign Policy Strategy.htm diakses pada 11 Juli 2017

"The Guardian. America dropped 26,171 bombs in 2016. What a bloody end to Obama's reign", 
117 Dwi Ardiyanti Imprediktabilitas Kebijakan Luar Negeri Amerika Serikat: Tantangan Dan Ancaman Rezim Donald Trump Terhadap Asean

"America dropped 26.171 bombs: 2016

Obama Legacy",

https://www.theguardian.com/commen tisfree/2017/jan/09/america-dropped26171-bombs-2016-obama-legacy, diakses pada 17 Oktober 2017 